\title{
Stearic sunflower oil as a sustainable and healthy alternative to palm oil. A review
}

\author{
Sanyal Anushree ${ }^{1,2} \cdot$ Merrien André $^{3} \cdot$ Decocq Guillaume ${ }^{1} \cdot$ Fine Frédéric $^{3}$
}

Accepted: 20 April 2017 / Published online: 17 May 2017

(C) The Author(s) 2017. This article is an open access publication

\begin{abstract}
Palm oil is widely used in the food industry because of its lower cost, high oxidative stability index, long shelf-life, and a reasonable replacement of trans fats. However, increased palm oil production reduces biodiversity, damages the ecosystem, and poses health risks to humans. Unsustainable development of palm plantations has caused deforestation and loss of natural habitat, rendering many species (Sumatran orangutans, elephants, and tigers) critically endangered. Similarly, decomposition and burning of carbon-rich soil in vast and deep peatlands is increasing carbon emissions. Furthermore, excessive consumption of palmitic acid (and other saturated fats except stearic acid) increases bad cholesterol and the risk of cardiovascular diseases. Therefore, we need healthier, stable, and solid/semisolid oils at room temperature with longer shelf-life and without trans fats. Here, we review the advancements in the development of sunflower oil varieties containing high stearic $(\sim 18 \%)$ and high oleic $(\sim 70 \%)$ acids which makes them healthy and sustainable alternatives to palm oil. First, the high-stearic-high-oleic
\end{abstract}

Sanyal Anushree

anushree.sanyal@ebc.uu.se

Merrien André

a.merrien@terresinovia.fr

Decocq Guillaume

guillaume.decocq@u-picardie.fr

Fine Frédéric

f.fine@terresinovia.fr

1 Unité "Ecologie et Dynamique des Systèmes Anthropisés" (EDYSAN, FRE 3498 CNRS), Université de Picardie Jules Verne, 1 rue des Louvels, FR-80037 Amiens Cedex, France

2 Department of Organismal Biology, Systematic Biology, Uppsala University, 75236 Uppsala, Sweden

3 Terres Inovia, 11 rue de Monceau, 75378 Paris Cedex 08, France sunflower crops can have grain and oil yield as high as 4036 and $1685 \mathrm{~kg} / \mathrm{ha}$ and oleic and stearic acid yield up to $\sim 73$ and $\sim 21 \%$. Second, high-stearic-high-oleic oils obtained from mutant and hybrid sunflower cultivars have higher oxidative stability index and therefore have better stability, quality, and functionality than regular sunflower oil. For example, the oxidative stability index of commercially available Nutrisun at $110^{\circ} \mathrm{C}$ is six times greater than that of regular sunflower oil. Finally, recent advances have made several mutant and hybrid cultivars with high grain and oil yield and high levels of stearic and oleic acids available. Given this progress, natural healthy high-stearic-high-oleic sunflower oil can now be grown in both the hemispheres in a sustainable manner with the currently available advanced technology and without damaging the ecosystem as is currently happening with palm oil cultivation.

Keywords Stearic sunflower $\cdot$ Sustainable $\cdot$ Palm oil · Greenhouse gas emission · Biodiversity $\cdot$ Ecology

Cardiovascular disease

\section{Contents}

1. Introduction

2. Agronomic aspects

2.1. Planting date, density and plant establishment

2.2. Climate

2.2.1 Drought and high temperatures

2.3 Yield

3. Breeding

4. Uses

5. Potential of the crop

6. Conclusion

Acknowledgements

References 


\section{Introduction}

Palm oil happens to be among the products which causes immense ecological damage. Increase in palm oil production occurs at the expense of biodiversity and damages the ecosystem. Forest cover in the Riau Province in Central Sumatra declined by $65 \%$ (4 million hectares) over the past 25 years from $78 \%$ in 1982 to $27 \%$ in 2007. Of the forest cover lost, $29 \%$ was cleared for industrial oil palm plantations (Uryu et al. 2008). Two models predicted that the forest cover would decline to 6 and 15\% (assuming full implementation of Riau's draft provincial land use plan) by 2015 . Oil palm plantations would contribute $27 \%$ (1.4 million hectares) of all the forest lost since 1982 (Uryu et al. 2008). Due to deforestation, loss of natural habitat, and unsustainable development of palm plantations, Sumatran orangutans, tigers (declined by $70 \%$, from 640 in 1982 to 192 in 2007), and elephants (declined by up to $84 \%$, from an estimated 1067-1617 in 1984 to possibly as few as 210 individuals in 2007) have been critically endangered (Uryu et al. 2008). Burning of trees and forests or peat swamps and also draining of peatlands to increase palm oil acreage release greenhouse gases into the atmosphere that contribute to global warming (Uryu et al. 2008; van der Werf et al. 2009). Hazardous pesticides and fertilizers like the herbicide paraquat pose a serious health hazard to the spray operators (Pesticides Action Network Asia Pacific 2009). Global consumption of palm oil and paper has been driving Riau's deforestation; it appears to also drive climate change. Reducing $\mathrm{CO}_{2}$ emissions would be far more effective if investments were allocated to the avoidance of deforestation. Furthermore, it has been reported that the consumption of palmitic acid increases the risk of cardiovascular diseases (WHO 2003; Chen et al. 2011), and much of the palm oil consumed in food is oxidized to the extent that when compared to the fresh state poses a health risk. Excessive intake and absorption of saturated fatty acids, other than stearic acid, generally has a negative effect on cardiovascular health.

The food industry currently needs healthier and more stable oils which are solid or semi-solid at room temperature (alternatives to hydrogenation and palm), have a longer shelf life, and without trans fats. Palm oil is one of the few highly saturated vegetable fats which is semi-solid at room temperature. The use of palm oil in the food industry is widespread because of its lower cost, high oxidative stability of the refined oil while frying, long shelf-life, and a reasonable replacement of trans fats from hydrogenated vegetable oils (McNamara 2010; Hayes and Pronczuk 2010) thus contributing to a healthy diet. Palm oil contains several saturated fatty acids (FAs) (lauric $(0.1 \%)$, myristic $(1 \%)$, palmitic $(44 \%)$, stearic $(5 \%)$ ) and unsaturated FAs (oleic (39\%), linoleic (10\%), and alphalinolenic $(0.3 \%))$. All the solid vegetable fats which can be classified into three groups (lauric, palmitic, and stearic fats) come from tropical species (Garcés et al. 2012).
Hence, a new alternative to palm oil which will be sustainable, easily accessible, cost effective, and compatible with a healthy diet is needed. Modern oilseed biotechnology has therefore targeted the production of fats enriched in saturated FAs mainly stearic acid, in common oil crops (Garcés et al. 2012). Several sunflower mutants with high stearic acid have been isolated by classical breeding and mutagenesis techniques thus avoiding concerns regarding the proliferation of genetically modified organisms in agriculture (MartinezForce and Garcés 1999). Some of these sunflower mutants express the high-stearic trait on a high-oleic background, and so their oil is enriched in triacylglycerols which are typically present in cocoa butter. Thus, the new high-stearic (HS) and high-stearic-high-oleic (HSHO) sunflower oil could be a reliable source of stearic-rich butter and an alternative to tropical fats. These oils can be fractionated to produce stearins enriched in stearic acid with physical properties similar to cocoa butter and other confectionary fats without hydrogenation or transesterification. These fats can be produced in temperate countries from a well-established crop like sunflower and would be a healthy source of saturated FAs (Garcés et al. 2012).

The most advance breeding program came from the Advanta Seeds Company. A high-stearate (15 to 20\%) sunflower oil in a high-oleic background is being commercialized under the brand name "Nutrisun" (Figs. 1 and 2).

High levels of saturated and low levels of polyunsaturated FAs made this HSHO sunflower oil more viscous and resistant to oxidation than those from common or high-oleic sunflower crops. The melting point of HSHO sunflower oils is also higher as it contains higher proportions of solid fats than common or high-oleic sunflower oils. However, this increase in the melting point was not close enough to those of high-stearic tropical butters like shea or cocoa butter. Different types of stearin fats, obtained by dry or solvent fractionation of HSHO sunflower oils, can have a high solid fat content at temperatures $>30^{\circ} \mathrm{C}$ which is even higher than cocoa butter or other high saturated tropical fats. This means that the HSHO oil itself cannot be used for confectionary applications and needs further processing before it can be a source for these fats. However, the solid fat content in Nutrisun can range from those of the original HSHO to hard stearin fractions with solid fat content values closer to shea and cocoa butter (Fig. 3) and has no trans fats. As an annual crop, Nutrisun oil has the potential of becoming the best competitive source of natural stearic acid when compared to other stearic sources and vegetable oils (Figs. 3 and 4). Nutrisun oil also has similar disaturated triacylglycerol content due to the presence of disaturated triacylglycerols rich in stearic acid and improved melting point due to the presence of arachidic and behenic acids in these disaturated triacylglycerols. Furthermore, these fats are also healthier than the actual fats made from palm, palm kernel, and coconut oils, or hydrogenated and 


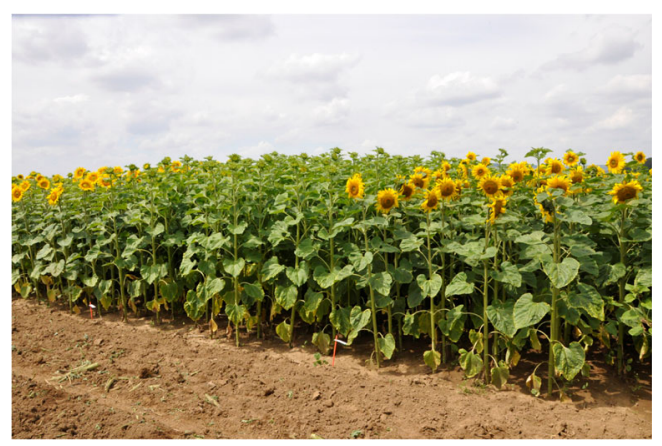

Fig. 1 A field trial of a sunflower crop in France. Photo credit: Terres Inovia

transesterified vegetable oils. The olein fraction is also very stable and can be a perfect substitute for nonfractionated oil in frying and bakery applications.

Synthesis of FAs in developing sunflower seeds takes place in the plastids and the endoplasmic reticulum (ER). From all the enzymes that participate to metabolize FAs, stearoyl-ACP desaturase ( $\mathrm{SAD}$, which has two isoforms in sunflower), oleoyl-CoA desaturase (OLD), and thioesterases (FAT A and B) are being highlighted. The SAD enzyme, which is located in the plastid, catalyzes the conversion of stearic to oleic acid through one unsaturation step at carbon-9 in the fatty acid hydrocarbonated chain. The OLD enzyme is in the ER and catalyzes the transformation of oleic to linoleic acid through the addition of a second unsaturation step at carbon-12. The FAT enzymes regulate the transportation of the FAs

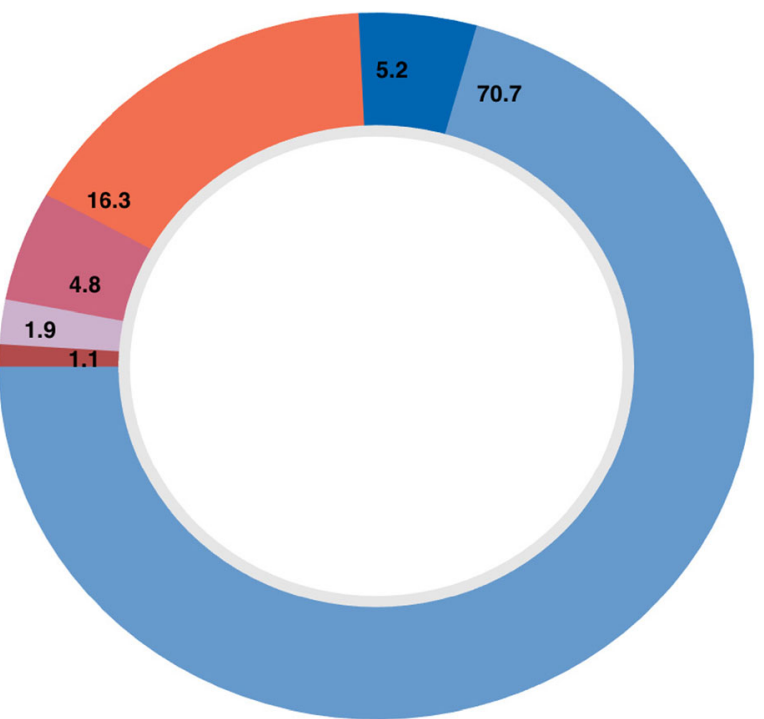

Oleic 18:1 Linoleic 18:2 Stearic 18:0 Palmitic 16:0 Behenic 22:0 Arachidic 20:0

Fig. 2 Characteristics of Nutrisun oil. Typical fatty acid composition of Nutrisun oil with high proportions of stearic and oleic acids and low proportions of palmitic acid making it a stable and healthy oil. The numbers represent the percent of the individual fatty acids. Data obtained from Advanta Seeds

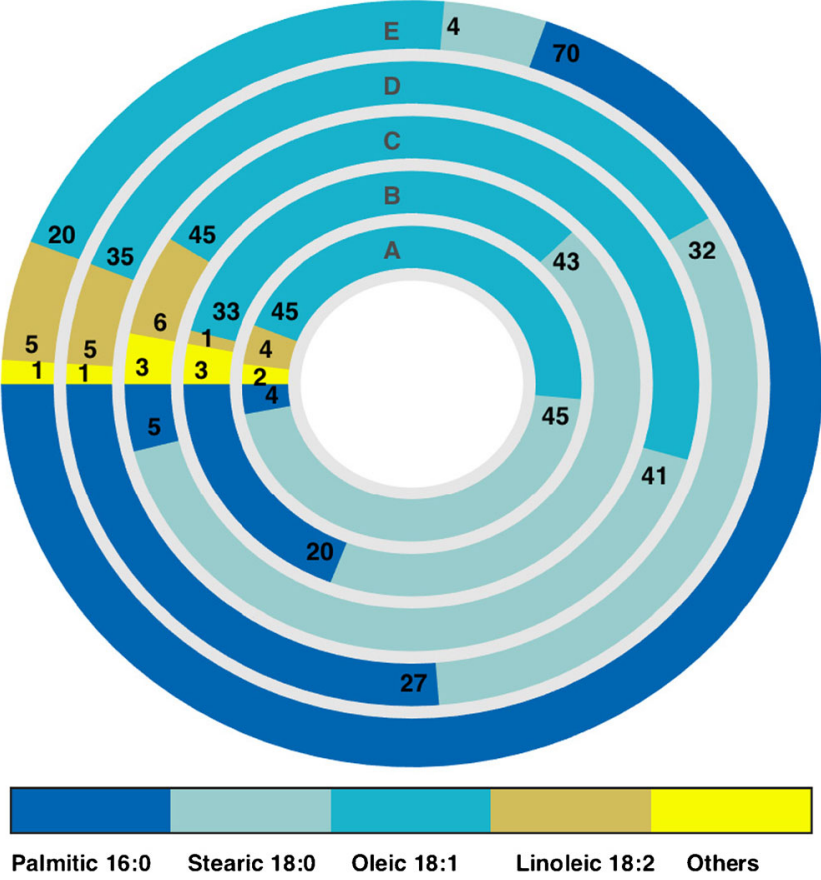

Fig. 3 Comparison of Nutrisun oil with other stearic sources. Nutrisun oil has the highest proportion of stearic acid and is the best source of natural stearic acid when compared with other stearic sources. $(A)$ Nutrisun stearin. $(B)$ Illipi butter. $(C)$ Shea butter. $(D)$ Cocoa butter. $(E)$ Palm stearin. The numbers in the concentric circles represent the percentages of the fatty acids

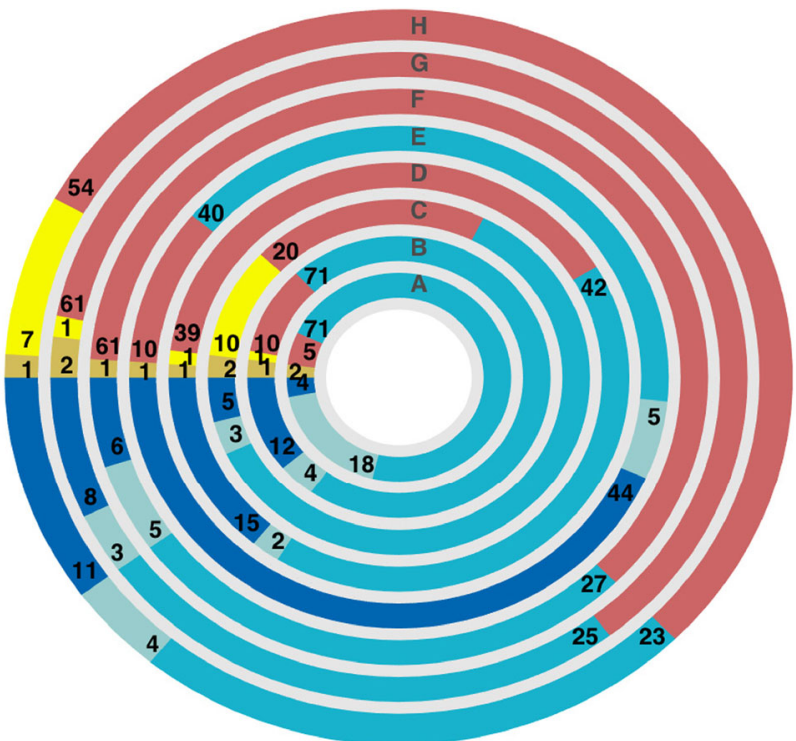

Palmitic 16:0Stearic 18:0 Oleic 18:1 Linoleic 18:2 Linolenic 18:3 Other Sat.

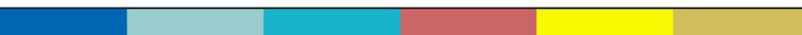

Fig. 4 Comparison of Nutrisun oil with other vegetable oils. Nutrisun oil has the highest proportion of stearic acid and is the best source of natural stearic acid when compared with other vegetable oils. $(A)$ Nutrisun HSHO. (B) Olive. (C) Rapeseed. (D) Rice tran. $(E)$ Palm. $(F)$ Regular sunflower. $(G)$ Corn. $(H)$ Soybean. The numbers in the concentric circles represent the percentages of the fatty acids 
synthesized in the plastid (palmitic, stearic, and oleic acids) to the ER (Martinez-Force and Garcés 2000).

\section{Agronomic aspects}

\subsection{Planting date, density, and plant establishment}

Previous studies on conventional and high-oleic sunflower hybrids have revealed that planting date, between-row distance, and plant density might affect the grain and oil yield and oil composition of high-stearic and high-stearic-higholeic sunflower crops.

Tests were carried out in a 2-year experiment (2009 and 2010) on the HSHO commercial hybrid (HS03) in Advanta's Biotechnology Center at Balcarce in Argentina. The HSHO sunflower hybrid used in the experiment was characterized as having short stature, medium yield potential, and early medium maturity. The evaluated factors were two planting dates (22nd and 25th October and 23rd and 25th November) in 2009 and 2010, two between-row-distance treatments $(0.70$, $0.52 \mathrm{~m})$, and three plant density levels $(40,000,65,000$ and 90,000 plants per hectare).

Weather conditions benefited the growth and development of Nutrisun HSHO sunflower hybrids in 2010 compared to 2009 for both planting dates at Balcarce in Argentina. Grain yields in 2010 were double of those in 2009 (2022.1 vs. $4035.9 \mathrm{~kg} / \mathrm{ha}$, Table 1) which agrees with previous studies (Flagella et al. 2002). Rainfall was greater throughout the growing season in 2010 compared to 2009 and may explain the increased yield in 2010 as the rainfall for early planting dates in October in 2009 was inadequate. Although in 2009 rains were more abundant early and late in the season, almost no difference was observed between years in the period $-10 /+20$ days around flowering for November planting date. The planting year and the interaction between planting year and date and their effect on grain and oil yield were significant (Table 1). Sunflower plots sown in October always had better yield than those planted in November (Table 1). Also, oil yield was greater for October planting dates and the difference among planting dates varied across years (Table 1) which was similar to what was reported by other researchers (Zheljazkov et al. 2009). The oil content proportions were 41.4 and $36.2 \%$ for October and November. The effect of early planting date on oil content derives from the most favorable conditions for incident radiation and temperature during the growing season. Oil content was observed to significantly decrease when sunflower was planted in November as well as when plant density was reduced. Seed oil content was the only variable affected by plant density $(41.4,42.5$, and $42.5 \%$ for the 40 , 65, and 90,000 plants/ha). Previous studies (Aguirrezabal and Pereyra 1998) showed that seed oil content remains almost constant across different plant densities whereas the other components of the kernel (i.e., hull, proteins) vary leading to changes in seed oil percentage. Seed oil composition was also affected by year and planting date. The stearic acid content was higher for early planting dates in 2009 but lower in 2010; the opposite response was true for the oleic acid content. Neither row spacing nor plant density affected the proportions of stearic or oleic acids. Although stearic and oleic acid content was affected by planting date, which might have been a consequence of different weather conditions. Studies show that genotype and weather seem to have a direct impact on oil content and fatty acid composition, and since HSHO sunflower hybrids have improved yield and oil content potential, further research to understand these interactions is needed (Cánepa et al. 2012).

Recently, sunflower hybrids differing in oil composition have been developed to provide for different industrial and human needs. France is probably the leading country for the oleic type (>75\%) sunflower cultivation covering 54

Table 1 Nutrisun hybrid performance in 2011, 2012, and 2013 (Cánepa et al. 2012)

\begin{tabular}{|c|c|c|c|c|c|c|c|c|c|c|c|c|}
\hline Season & Hybrid & Type & $\begin{array}{l}\text { Flowering } \\
\text { (days) }\end{array}$ & $\begin{array}{l}\text { Height } \\
(\mathrm{cm})\end{array}$ & $\begin{array}{l}\text { Grain yield } \\
(\mathrm{kg} / \mathrm{ha})\end{array}$ & $\begin{array}{l}\text { Oil } \\
(\%)\end{array}$ & $\begin{array}{l}18: 0 \\
(\%)\end{array}$ & $\begin{array}{l}18: 1 \\
(\%)\end{array}$ & $\begin{array}{l}\text { Relative } \\
\text { oil }(\%)\end{array}$ & $\begin{array}{l}\text { Oil yield } \\
\text { (kg/ha) }\end{array}$ & $\begin{array}{l}\text { Relative grain } \\
\text { yield/ha }(\%)\end{array}$ & $\begin{array}{l}\text { Relative oil } \\
\text { yield/ha (\%) }\end{array}$ \\
\hline October 2009 & HSO3 & HSHO & & & 2022.1 & & 20.3 & 69.9 & & 836.4 & & \\
\hline November 2009 & $\mathrm{HS} 03$ & HSHO & & & 1751.9 & & 17.9 & 72.9 & & 663.4 & & \\
\hline October 2010 & $\mathrm{HS} 03$ & HSHO & & & 4036 & & 17.9 & 72 & & 1685.1 & & \\
\hline November 2010 & HS03 & HSHO & & & 2991.8 & & 21.3 & 69.3 & & 1152.6 & & \\
\hline $2013^{\mathrm{a}}$ & MS06 & MSHO & 76 & 127.8 & 3467.6 & 49.3 & & & 94.9 & 1709.9 & 87.0 & 82.7 \\
\hline $2013^{\mathrm{a}}$ & HS03 & HSHO & 73.4 & 124.4 & 2993.9 & 45.2 & & & 87.1 & 1358.2 & 75.2 & 65.6 \\
\hline $2011,2012,2013^{\mathrm{b}}$ & MS06 & MSHO & 77.2 & 130.1 & 3386.9 & 45.3 & & & 91.5 & 1536.5 & 89.5 & 81.8 \\
\hline $2011,2012,2013^{\mathrm{b}}$ & $\mathrm{HS} 03$ & HSHO & 73.9 & 119.3 & 2869.4 & 42.1 & & & 85.0 & 1212.9 & 75.8 & 64.5 \\
\hline
\end{tabular}

${ }^{a}$ Nine plants of the hybrids were grown at three locations in Levroux (France)

${ }^{b}$ Eighteen plants of the hybrids were grown at six locations at L'Isle Jourdain and Peyrens (France) in 2012 and 2013 
and $57 \%$ of the total acreage in 2010 and 2011. The 5-year ONIDOL/TERRES INOVIA survey from 2006 to 2010 showed that the mean oleic acid content in France ranged between 85.4 and $86.7 \%$ (Labalette et al. 2012). These oils are characterized by the relative amount of saturated, mono-, and polyunsaturated fatty acids. Fatty acid composition varied depending on year, location, genotype, cultural practices, and environmental conditions (primarily temperature).

\subsection{Climate}

\subsubsection{Drought and high temperatures}

In the high stearic acid containing CAS-14 mutant, the stearic acid content increased with increasing temperatures. The highest stearic acid seeds were obtained from the plants that produced the seeds during the period of maximum summer temperatures $\left(35-40{ }^{\circ} \mathrm{C}\right.$ during the day and $20-25^{\circ} \mathrm{C}$ at night) (Fernandez-Moya et al. 2002) whereas in the medium stearic containing CAS-3 and CAS-4 mutants, and a high stearic acid containing line ADV-3512, the stearic acid proportions decreased at high temperatures (Izquierdo et al. 2013). The CAS-14 mutant line has more stearic acid $(37.3 \%)$ than the previous highstearic-acid sunflower mutants like CAS-3 which had 28.8\% stearic acid (Fernandez-Moya et al. 2002; Osorio et al. 1995). Due to the sensitivity of desaturases to temperature, high temperatures increase the content of monounsaturated fatty acids (C18:1) (Merrien et al. 2005).

An effect of temperature on the high-stearic-acid sunflower mutants was observed. Temperatures higher than $30 / 20{ }^{\circ} \mathrm{C}$ (day/night temperatures) were required for the expression of the phenotype of the CAS-14 mutant. Seeds from CAS-14 plants were subjected to three different high temperature treatments and seeds were collected for fatty acid half-seed analysis. As expected, the stearic acid content increased with temperature, mainly from $30 / 20$ to $35 / 22{ }^{\circ} \mathrm{C}$ (14.2 and $34.0 \%$, respectively). The maximum stearic acid (37.3\%) content was obtained at 39/24 ${ }^{\circ} \mathrm{C}$ (Fernandez-Moya et al. 2002). A similar effect was found in the contents of the other saturated fatty acids: palmitic, arachidic, and behenic acids. Thus, a new type of temperature regulation on the stearate desaturation must be occurring.

The relationship between the growth temperature and the stearic acid content found in CAS-14 was the opposite of what was previously observed in normal sunflower oils, in which more stearic acid was produced at low temperatures (Lajara et al. 1990). In a study covering 33 field locations in Spain, it was observed that the stearic acid content decreased progressively from 6 to $3.2 \%$ from Northern Spain (colder weather) to Southern Spain (warmer weather). Also, in the medium stearic acid mutants
CAS-4 and CAS-8, an inverse relationship between growth temperature and stearic acid proportions was reported. At $30 / 20{ }^{\circ} \mathrm{C}$ day/night temperature, these mutants had $11-$ $12 \%$ stearic acid, whereas at $20 / 10{ }^{\circ} \mathrm{C}$, they contained 18-20\% stearic acid (Martínez-Force et al. 1998). In another study by Izquierdo et al. (2013) with the CAS-3 mutant, the stearic acid content at $16 / 16^{\circ} \mathrm{C}$ was higher than at $26 / 26^{\circ} \mathrm{C}$ (26.2 vs. $18.4 \%$ ) during the grain filling period. This study also found the highest variation in the fatty acid composition in the CAS-3 mutant. This pattern was also observed in another treatment (16/16, 26/16, 26/26, and $32 / 26^{\circ} \mathrm{C}$ ) where the stearic acid content was higher for two (CAS-3 and ADV-3512) of the three high-stearic inbred lines and two (ADV-3807 and ADV-2803) of the three HSHO inbred lines at lower temperatures. A reduction of approximately $10 \%$ in the concentration of stearic acid was observed between extreme treatments (Izquierdo et al. 2013).

\subsection{Yield}

Nutrisun medium-stearic-high-oleic (MSHO) hybrid MS06 and HSHO hybrid (HS03) developed by the Instituto de la Grasa of Sevilla, CSIC (Superior Council of Scientific Research) in Spain and Advanta Seeds were grown in France in 2011, 2012, and 2013 and HS03 was grown at Balcarce in Argentina in 2009 and 2010 and the yields are shown in Table 1. The first Nutrisun crop was harvested in Argentina in 2008, then in Spain in 2009, and the USA in 2010 .

A field experiment was conducted in 2014 in the Atlantic border region (Surgères) in France (Fig. 5). The performance of the stearic Nutrisun hybrid was the same as the other sunflower types.

\section{Breeding}

The novel fatty acid traits are in all cases governed by a reduced number of genes and can be easily managed in breeding programs aimed at developing cultivars incorporating these traits (Fernández-Martínez et al. 2007). High-stearic-acid oils on standard backgrounds or high-oleic backgrounds suitable for the production of more healthy margarines obtained through conventional plant breeding have been commercialized or are foreseeable in a few years (Fernández-Martínez et al. 2007).

Some breeding objectives are associated with the traits or properties desired by the food industry like oil with highstearic acid is desirable for preparation of margarine and other specialty products and also because it does not increase the serum cholesterol level. 
Fig. 5 Comparison of the performances of the Nutrisun hybrids, oleic, and conventional sunflowers in the west Atlantic region in France in 2014. The field experiment showed that the performance of the stearic Nutrisun hybrid was the same as the other sunflower types

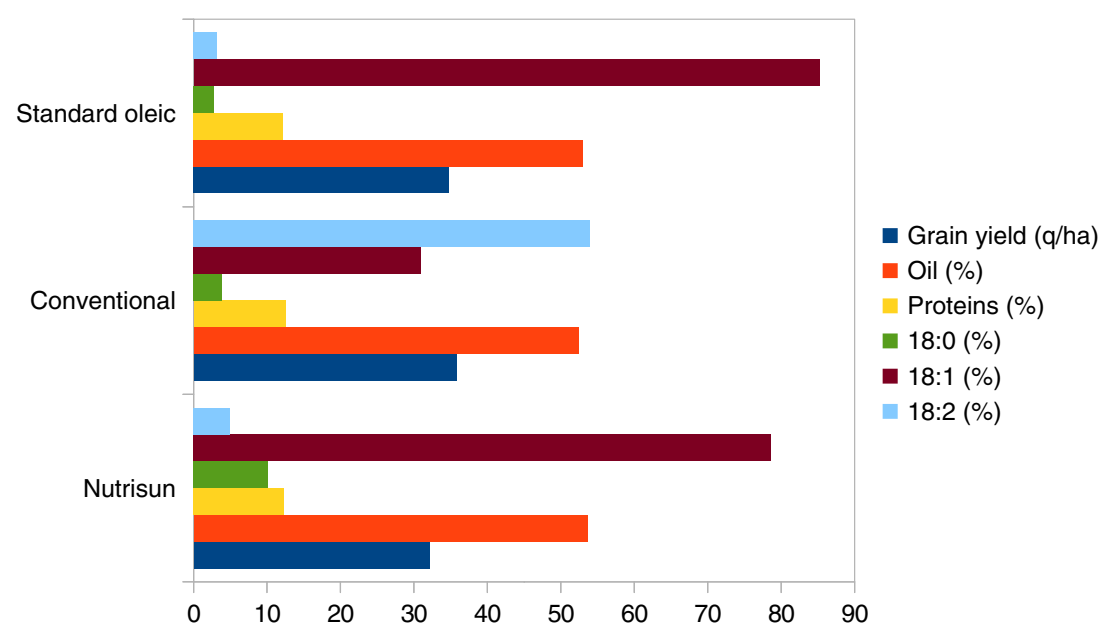

Several Helianthus annuus cultivars with high-stearic acid content were generated to increase the variability of the trait in the standard lines by using mutagenesis or crossing screened mutants with high stearic acid proportions with standard lines (Table 2). Furthermore, high-stearic-high-oleic (HSHO) sunflower oil called Nutrisun ${ }^{\mathrm{TM}}$ developed by Advanta Seeds was obtained through conventional breeding (non-GMO), molecular marker-assisted selection, and analytical techniques which allowed for a more efficient selection of the individuals of interest (Pleite et al. 2006).

Mutagenesis has been successfully used for developing variation in the fatty acid profile of sunflower. The mutants CAS-8, CAS-4, and CAS-3 with medium to high stearic acid proportions (Osorio et al. 1995) and CAS-14 with very high stearic acid proportions (Fernandez-Moya et al. 2002) have been developed. Further, CAS-29 and CAS-30 also have very high stearic acid proportions (Fernandez-Moya et al. 2005) and CAS-19 and CAS-20 have medium stearic acid proportions (Pérez-Vich et al. 2004) (Table 3). All these traits are usually under embryonic control by few genes (FernandezMartínez et al. 2004) which facilitate their management in breeding programs. For example, three genes (Es1, Es2, and Es3) are involved in the control of high stearic acid proportions and one or two genes in the control of low levels of these fatty acids. Moreover, in recent years, molecular markers have been developed for high stearic and high oleic acid
Table 2 The phenotype based on the fatty acid composition $(\%)$ of the seed oil of the principal induced and natural mutant cultivars of sunflower, in comparison with the standard type

\begin{tabular}{llll}
\hline Line & Phenotype & Origin & References \\
\hline CAS-3 & HS & RDF-1-532 & Osorio et al. 1995 \\
CAS-4 & HS & RDF-1-532 & Osorio et al. 1995 \\
CAS-8 & MS & RDF-1-532 & Osorio et al. 1995 \\
CAS-14 & VHS & CAS-10 & Fernandez-Moya et al. 2002 \\
CAS-19 & MS & CAS-3 $\times$ HA 89 & Pérez-Vich et al. 2004 \\
CAS-20 & MS & CAS-3 $\times$ HA 89 & Pérez-Vich et al. 2004 \\
CAS-29 & VHS & CAS-3 $\times$ CAS-4 & Fernandez-Moya et al. 2005 \\
CAS-30 & VHS & Selection from CAS-3 & Fernandez-Moya et al. 2005 \\
ADV-2504 & HS & & Izquierdo et al. 2013 \\
ADV-3512 & HS & & Izquierdo et al. 2013 \\
CAS-15 & HSHO & CAS-3 $\times$ RHA-345 & Fernandez-Moya et al. 2005 \\
CAS-33 & MSHO & CAS-3 $\times$ RHA-345 & Fernandez-Moya et al. 2005 \\
ADV-3807 & HSHO & & Izquierdo et al. 2013 \\
ADV-2803 & HSHO & & Izquierdo et al. 2013 \\
ADV-3816 & HSHO & & Izquierdo et al. 2013 \\
Nutrisun & HSHO & & Advanta Seeds \\
\hline
\end{tabular}


Table 3 Fatty acid composition in high stearic acid, parental, and standard lines of sunflower, regular sunflower, and palm

\begin{tabular}{llllllll}
\hline Fatty acid (\%) & $16: 0$ & $18: 0$ & $18: 1$ & $18: 2$ & $20: 0$ & $22: 0$ & References \\
\hline BSD-2-691 & $5.5 \pm 7$ & $4.0 \pm 15$ & $29.0 \pm 30$ & $60.0 \pm 60$ & & Osorio et al. 1995 \\
RHA-274 $^{\mathrm{a}}$ & $6.1 \pm 7$ & $4.8 \pm 15$ & $35.0 \pm 67$ & $53.9 \pm 72$ & & & Osorio et al. 1995 \\
RDF-1-532 $^{\mathrm{b}}$ & $5.6 \pm 5$ & $5.5 \pm 14$ & $30.4 \pm 56$ & $58.3 \pm 67$ & & & Osorio et al. 1995 \\
CAS-3 & 7.8 & 28.8 & 21.5 & 41.9 & & & Osorio et al. 1995 \\
CAS-4 & 8.8 & 16.1 & 40.8 & 34.3 & & & Osorio et al. 1995 \\
CAS-8 & 7.8 & 14.8 & 28.8 & 48.6 & & & Osorio et al. 1995 \\
CAS-29 & 7.2 & 34.5 & 13.0 & 41.7 & 1.8 & 1.8 & Fernandez-Moya et al. 2005 \\
CAS-30 & 6.6 & 30.3 & 10.2 & 49.6 & 1.5 & 1.8 & Fernandez-Moya et al. 2005 \\
CAS-19 & 7.2 & 21.5 & 19.9 & 48 & 1.8 & 1.6 & Fernandez-Moya et al. 2005 \\
CAS-20 & 6.0 & 10.0 & 38.3 & 43.7 & 0.4 & 1.6 & Fernandez-Moya et al. 2005 \\
CAS-15 & 5.4 & 24.9 & 57.8 & 8.2 & 1.8 & 1.9 & Fernandez-Moya et al. 2005 \\
CAS-14 & 8.4 & 37.3 & 12.4 & 38.0 & & & Fernandez-Moya et al. 2002 \\
Nutrisun HSHO & 4.8 & 16.3 & 70.7 & 5.2 & 1.1 & 1.9 & Advanta Seeds \\
CAS-33 & 6.1 & 17.4 & 64.1 & 9.7 & 1.1 & 1.7 & Fernandez-Moya et al. 2005 \\
Regular & 6 & 5 & 27 & 61 & & & Advanta Seeds \\
$\quad$ sunflower & & & & & & & Advanta Seeds \\
Palm & 44 & 5 & 40 & 10 & & & \\
\hline
\end{tabular}

${ }^{\mathrm{a}}$ Check line

${ }^{\mathrm{b}}$ Parental line for the CAS-3, CAS-4, and CAS-8 mutant lines proportions (Pérez-Vich et al. 2002). The use of these molecular markers will contribute towards improving breeding efficiency (Fernández-Martínez et al. 2007).

In several studies, the molecular nature of high stearic acid mutants were investigated in order to increase the stearic acid proportions for improved quality of sunflower oil, which is a desirable breeding objective for food-processing applications (Pérez-Vich et al. 2006).

Molecular markers have enabled detailed characterization of the CAS-3 mutant. Classical genetic studies indicate that the two partially recessive genes (Es1 and Es2) are involved in the genetic control of the high C18:0 trait in this line (C18:0 genotype es1es1es2es2) (Pérez-Vich et al. 1999). The Es1 locus has the greatest effect on C18:0 levels, but both Es loci had an additive effect on the proportions of C18:0 (Pérez-Vich et al. 1999, 2004a). Candidate gene and quantitative trait loci (QTL) analysis revealed the co-location of a major QTL affecting stearic acid proportions with a gene of known function in the seed fatty acid biosynthetic pathway. A stearoyl-acyl carrier protein desaturase locus (SAD17A) which desaturates stearate to oleate in the de novo biosynthesis of fatty acids in the stroma of seed plastids was found to co-segregate with Es 1 (Pérez-Vich et al. 2002). Using RFLP-AFLP linkage maps constructed from two different mapping populations derived from CAS-3, the SAD17A locus was mapped to the linkage group (LG) 1 of the sunflower genetic map, according to the LG nomenclature of Berry et al. (1997), and was found to underlie the major QTL affecting the concentration of C18:0. This QTL explained around 80\% of the phenotypic variance of stearic acid (Pérez-Vich et al. 2002). Other minor QTL affecting stearic acid content which mapped to LG3, LG7, and LG13 were also identified in this study. However, these QTL were neither consistent across mapping populations nor with the various methods used to perform the QTL analyses. Therefore, none of the minor QTL was considered as strong candidates for the Es2 locus (Pérez-Vich et al. 2002).

Another QTL study for high stearic acid proportions in sunflower was performed (Perez-Vich et al. 2004a). The sunflower line CAS-20 (C18:0 genotype Es1Es1es2es2), developed from the high C18:0 mutant line CAS-3 (C18:0 genotype es 1es1es2es2; 25\% C18:0), had increased C18:0 levels in its seed oil (8.6\%). QTL conferring increased C18:0 proportions in CAS-20 was mapped in a F2 mapping population developed from crosses between HA-89 (wild-type Es1Es1Es2Es2) with low C18:0 and CAS-20 (C18:0 genotype Es1Es1es2es2), which segregated independent of the macromutation at Es 1 controlling high C18:0 proportions in CAS-3. A genetic map of 17 LGs comprising of 80 RFLP and 19 SSR marker loci from this population was used to identify the QTL controlling the fatty acid composition. Three QTL affecting C18:0 proportions were identified on LG3, LG11, and LG13, with all the alleles for increased C18:0 proportions inherited from CAS-20. In total, these QTL explained $43.6 \%$ of the total phenotypic variance of C18:0 and have been attributed to the segregation of the Es 2 locus. 
Furthermore, four candidate genes (two stearate desaturase genes, SAD6 and SAD17, FAT A and FAT B thioesterase genes) involved in C18:0 biosynthesis and an oleate-desaturase (OLD)-like gene were mapped in this study. Based on the positional information, it was suggested that the QTL on LG11 was a SAD6 locus. The results showed that the increased C18:0 proportions in sunflower seed oil are a complex trait, and the markers flanking these QTL constitute a powerful tool for plant breeding programs.

In another study (Pérez-Vich et al. 2006), the molecular nature of the high stearic acid mutant (CAS-14) line ( $>35 \%$ vs. $<6 \%$ in currently grown sunflower hybrids) which is controlled by the Es 3 gene was investigated. However, the expression of the high stearic acid trait in CAS-14 is strongly influenced by temperature during seed maturation. Two F2 mapping populations were developed from crosses between CAS-14 and P21, a nuclear male sterile line with the Ms11 gene controlling this trait, and between CAS-14 and CAS-3. One hundred thirty-three individuals from P21 $\times$ CAS-14 and 164 individuals from CAS-3 $\times$ CAS-14 were phenotyped for fatty acid composition using gas-liquid chromatography from the F2 and F3 generations, and they were then genotyped with SSR and insertion-deletion markers. Bulk segregant analysis in the P21 $\times$ CAS-14 population identified two markers on LG 8 putatively linked to Es3. Es 3 mapped to the distal half of LG8 and was flanked by the SSR markers ORS243 and ORS1161 at genetic distances of 0.5 and $3.9 \mathrm{cM}$. The Ms11 gene was also mapped to LG8 and the genetic distance between this gene and $E s 3$ was found to be $7.4 \mathrm{cM}$. In the CAS-3 $\times$ CAS-14 population, two QTLs were identified on LG1 and LG8, which underlie the Es 1 gene from CAS-3 and the Es 3 gene from CAS-14. A significant epistatic interaction between these two QTLs was found. Results from this study provided a basis for determining CAS-14 breeding strategies.

The selection for QTLs using genetic markers can be effective if a significant association is found between the quantitative trait and the genetic markers and these associations can be used to develop improved lines or populations (MAS). QTL regions obtained from one population can later be introgressed into other varieties, which may be more suited for specific environments (Dudley 1993).

\section{Uses}

Increased levels of C18:0 have an additional advantage over other saturated FAs because of its neutral effect on serum lipoprotein cholesterol (Pearson 1994). Individual saturated FAs like lauric (C12:0), myristic (C14:0) and palmitic
(C16:0) acids increase LDL (bad) cholesterol whereas stearic (C18:0) acid has no effect (FAO 2010).

At present, stearic acid is the only option for making safe solid fats (Crupkin and Zambelli 2008; Valenzuela et al. 2011). Increasing saturated FAs produces oil that can be used in food and cosmetic products by decreasing the need for substantial amounts of hydrogenation (Fernández-Martínez et al. 2007). The manufacture of margarine and other specialty products requires solid or semisolid fats, but standard sunflower oil, comprising primarily of unsaturated FAs, is liquid at room temperature. Hence, prior to its utilization in the food industry usually chemical hardening to change to a solid or semi-solid state, generally by hydrogenation or transesterification is needed. However, trans-fatty acids produced during these processes are harmful and related to heart diseases (Ascherio and Willett 1997). Hence, increased levels of saturated fats are desirable for the margarine and other related industries for the development of solid or semi-solid fats with the purpose of avoiding harmful chemical processes like hydrogenation or transesterification (Ascherio and Willett 1997; Kritchevsky et al. 1995).

\section{Potential of the crop}

As an annual crop of HSHO oil, Nutrisun has the potential of becoming the best competitive source of natural stearic acid. The production of a natural sunflower oil with relatively high stearic (18\%) and oleic $(70 \%)$ acid proportions not only serves the purpose of avoiding the hydrogenation process and the use of oils with unhealthy saturated fats (myristic, lauric, palmitic) as the proportions of palmitic acid is low (4\%), but gives more oxidative stability to the sunflower oil. Its higher oxidative stability due to the low content $(<4 \%)$ of polyunsaturated fatty acids increases shelf life and yields and provides trans-free alternative for industrial frying processes, and the neutral taste does not affect the taste of food cooked in it. Regular sunflower oil is a liquid at temperatures $>-10{ }^{\circ} \mathrm{C}$ while $\mathrm{HSHO}$ begins to have solid fat at temperatures $<15{ }^{\circ} \mathrm{C}$. Stearic acid is the only saturated fatty acid that does not affect the plasmatic levels of LDL (bad) and HDL (good) cholesterol. Foods that are high in stearic acid, such as dark chocolate and shea nut oil, need not be considered as harmful as foods high in other saturated fatty acids or trans fatty acids. Furthermore, limiting the energy from the cholesterolraising fats to less than 5 to $7 \%$ will help to maintain blood cholesterol at desirable concentrations.

The presence of high proportions of stearic acid allows the use of HSHO sunflower oil or its derived products (oleins and stearins) from the fractional crystallization process (Bootello et al. 2011) in applications requiring 
Fig. 6 Comparison of the oxidative stability index (OSI) values of high-stearic-high-oleic (HSHO) sunflower oil with other commercial oils shows that the OSI of HSHO is high, indicating significant improvements in performance, stability, quality, and functionality, and the possibility of replacing the use of partially hydrogenated oils and eliminating trans fats while maintaining the same oxidative stability. Adapted from Dubinsky and Garces Mancheño (2011)

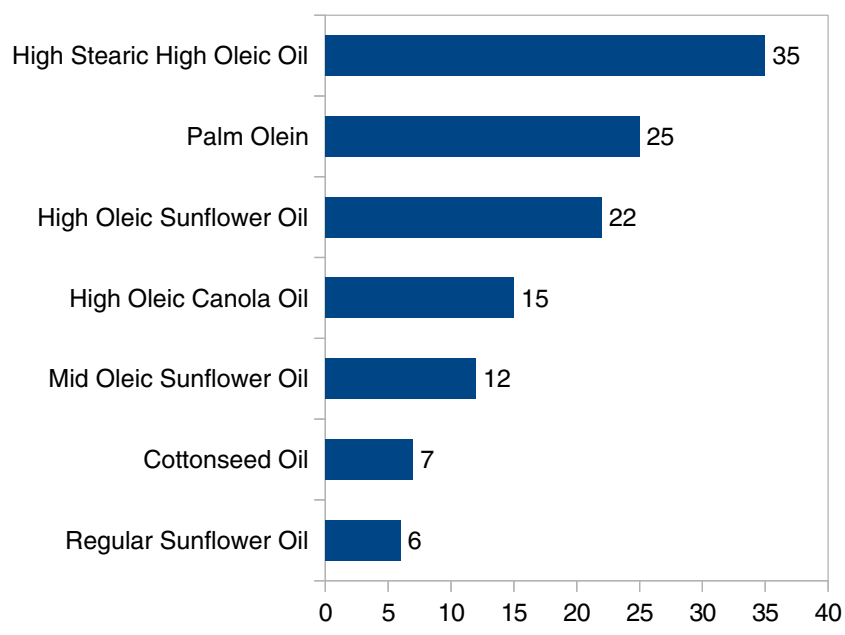

- OSI hours at $110^{\circ} \mathrm{C}$ solid fats instead of trans or other saturated fats: for example, in margarines, toppings and fillings, fried snacks, confectionery coatings, and for bread products in the bakery (Dubinsky and Garces Mancheño 2011). The oil stability index of Nutrisun at $110{ }^{\circ} \mathrm{C}$ is 1.6 and six times greater than high-oleic and regular sunflower oil (Fig. 6). Thus, HSHO sunflower oil offers the possibility of replacing the use of partially hydrogenated oils, eliminating trans fats and maintaining the same oxidative stability. HSHO sunflower oil began to be marketed in 2008 for tests in the food industry, mainly in industrial frying. Those tests showed significant improvements in terms of performance, stability, quality, and functionality and produced food with an organoleptic profile completely acceptable to consumers.

The "know-how" of the farmers in producing sunflower crops and their ability to produce two types of sunflowers (conventional and oleic) through separate organization will enable them to grow stearic sunflower on a larger scale across the world in future. Since Nutrisun HSHO is a natural product obtained from sunflower seeds using the most advanced technology, it can be produced in similar conditions across the globe ensuring the availability of the product in both the hemispheres. Agronomic characteristics and effects of abiotic stress on the fatty acid profiles will need to be considered.

\section{Conclusion}

The problems and challenges of global climate change due to release of greenhouse gases from burning forests, peatland swamps, and draining of peatlands for palm oil cultivation, loss of biodiversity due to loss of natural habitat, suggest that we are in urgent need of an alternate sustainable, healthier stearate sunflower oil. Methods and technology developed for producing HSHO sunflower oil and the availability of mutants with high stearic acid content will be very useful to develop sunflower oil with higher proportion of stearic acid and provide a healthy and stable substitute to palm oil. The highstearic sunflower oil will help fight cardiovascular diseases and bring health benefits to the consumers by the progressive replacement of hydrogenated and trans-fatrich oils in human food. It will provide stable, healthy, and solid cooking oils. The high-stearic-high-oleic sunflower seeds produced by Advanta seeds can be obtained by conventional breeding techniques (non-GMO) and are similar to conventional sunflower. Hence, in the near future, it will be possible to develop a greater variety and quantity of healthy high-stearic sunflower oil.

Acknowledgements This work was conducted while AS held a postdoc fellowship from the S.A.S. PIVERT ("Institut d'Excellence en Energie Décarbonée," funded by the French ANR) and was financially supported within the framework of the Precompetitive Research programme "Genesys."

Open Access This article is distributed under the terms of the Creative Commons Attribution 4.0 International License (http:// creativecommons.org/licenses/by/4.0/), which permits unrestricted use, distribution, and reproduction in any medium, provided you give appropriate credit to the original author(s) and the source, provide a link to the Creative Commons license, and indicate if changes were made.

\section{References}

Aguirrezabal LAN, Pereyra VR (1998) Sunflower. In: Aguirrezabal LAN, FH Andrade (ed) Calidad de productos agrícolas. Bases ecofisiológicas, genéticas y de manejo agronómico. Unidad Integrada Balcarce pp 139-192

Ascherio A, Willett WC (1997) Health effects of trans-fatty acids. Am J Clin Nutr 66(Suppl):1006s-1101s

Berry ST, Leon AJ, Peerbolte R, Challis C, Livini C, Jones R, Feinglod S (1997) Presentation of the Advanta sunflower RFLP linkage map for 
public research. In: Proc 19th Sunflower Res. Workshop. Fargo, USA

Bootello MA, Garces Mancheño R, Martinez Force E, Salas J (2011) Dry fractionation and crystallization kinetics of high-oleic high-stearic sunflower oil. J Am Oil Chem Soc 88(10):1511-1519

Cánepa M, Paccapelo V, Grondona M, Bazzalo ME, Reid R (2012) Planting date, between-row distance and population effect on grain yield and oil, stearic and oleic oilseed content on a high stearic-high oleic sunflower hybrid. In: Proc 18th International Sunflower Conference, Mar del Plata, Argentina

Chen BK, Seligman B, Farquhar JW, Goldhaber-Feibert JD (2011) Multicountry analysis of palm oil consumption and cardiovascular disease mortality for countries at different stages of economic deveopment: 1980-1997. Glob Health 7:45

Crupkin M, Zambelli A (2008) Detrimental impact of trans fats on human health: stearic acid-rich fats as possible substitutes. Compr Rev Food Sci Food Saf 7(3):271-279. doi:10.1111/j.1541-4337.2008.00045.x

Dubinsky E, Garces Mancheño R (2011) High-stearic/high-oleic sunflower oil: a versatile fat for food applications. Int News Fats Oils Relat Mater (INFORM) 22(6):369-372

Dudley JW (1993) Molecular markers in plant improvement: manipulation of genes affecting quantitative traits. Crop Sci 33:660-668. doi: 10.2135/cropsci1993.0011183X003300040003x

FAO (2010) Fats and fatty acids in human nutrition-report of an expert consultation. Food and Nutrition Paper 91, Food and Agriculture Organization of the United Nations, Geneva

Fernandez-Martínez JM, Velasco L, Pérez-Vich B (2004) Progress in the genetic modification of sunflower oil quality. In: Proc. 16th International Sunflower Conference, Fargo, USA

Fernández-Martínez JM, Pérez-Vich B, Velasco L, Domínguez J (2007) Breeding for specialty oil types in sunflower. Helia 30(46):75-84. doi:10.2298/HEL0746075F

Fernandez-Moya V, Martinez-Force E, Garcés R (2002) Temperature effect on a high stearic acid sunflower mutant. Phytochemistry 59: 33-37. doi:10.1016/S0031-9422(01)00406-X

Fernandez-Moya V, Martínez-Force E, Garcés R (2005) Oils from improved high stearic acid sunflower seeds. J Agric Food Chem 53(13):5326-5330. doi:10.1021/jf0503412

Flagella Z, Rotunno T, Tarantino E, Di Caterina R, De Caro A (2002) Changes in seed yield and oil fatty acid composition of high oleic sunflower (Helianthus annuus L.) hybrids in relation to the sowing date and the water regime. Eur J Agronomy 17:221-230. doi:10.1016/s1161-0301(02)00012-6

Garcés R, Martinez-Force E, Salas JJ, Bootello MA (2012) Alternatives to tropical fats based on high-stearic sunflower oils. Lipid Technol 24(3):63-65. doi:10.1002/lite.201200182

Hayes KC, Pronczuk A (2010) Replacing trans fat: the argument for palm oil with a cautionary note on interesterification. Report. J Am Coll Nutr 29(3 Suppl):253S-284S

Izquierdo NG, Aguirrezábal LAN, Martínez-Force E, Garcés R, Paccapelo V, Andrade F, Reid R, Zambelli A (2013) Effect of growth temperature on the high stearic and high stearic-high oleic sunflower traits. Crop Pasture Sci 64:18-25. doi:10.1071/CP12437

Kritchevsky D, Tepper SA, Kuksis A, Eghtedary K, Klurfeld DM (1995) Influence of triglyceride structure on experimental arteriosclerosis. FASEB J 9:A320

Labalette F, Jouffret P, Merrien A (2012) Oleic sunflower production: current situation and trends for the future. In: Proc of 18th International Sunflower Conference, Mar del plata, Argentina

Lajara J, Diaz U, Quidiello R (1990) Definite influence of location and climatic conditions on the fatty acid composition on sunflower seed oil. J Am Oil Chem Soc 67:618-623. doi:10.1007/BF02540410

Martinez-Force E, Garcés R (1999) New oilseed varieties with modified fatty acid composition in the oil. Trends Agron 2:13-21
Martinez-Force E, Garcés R (2000) Metabolic control analysis of de novo sunflower fatty acid biosynthesis. Biochem Soc Trans 28:669-671. doi: $10.1042 / b s t 0280669$

Martínez-Force E, Álvarez-Ortega R, Cantisán S, Garcés R (1998) Fatty acid composition in developing high saturated sunflower (Helianthus annuus L.) seeds: maturation changes and temperature effect. J Agric Food Chem 46:3577-3582. doi:10.1021/jf980276e

McNamara DJ (2010) Palm oil and health: a case of manipulated perception and misuse of science. Report. J Am Coll Nutr 29(3 Suppl):240S-244S

Merrien A, Pouzet A, Krouti M, Dechambre J, Garnon V (2005) Contribution à l'étude de l'effet des températures basses sur la composition en acide gras de l'huile des akènes de tournesol (oléique et classique) OCL 12: 455-458. doi: 10.1051/ocl.2005.0455

Osorio J, Fernández-Martínez JM, Mancha M, Garcés R (1995) Mutant sunflower with high concentration in saturated fatty acid in the oil. Crop Sci 35:739-742. doi:10.2135/cropsci1995. 0011183X003500030016x

PAN AP (2009) Call for immediate ban of paraquat and class 1 pesticides and progressive ban of highly hazardous pesticides in oil palm plantations, Press statement

Pearson TA (1994) Stearic acid: a unique saturated fatty acid. Am J Clin Nutr 60(Suppl. 1):983S-1072S

Pérez-Vich B, Garcés R, Fernández-Martinez JM (1999) Genetic control of high stearic acid content in the seed oil of the sun-flower mutant CAS-3. Theor Appl Genet 99:663-669. doi:10.1007/ s001220051282

Pérez-Vich B, Fernández-Martínez JM, Grondona M, Knapp SJ, Berry ST (2002) Stearoyl-ACP and oleoyl-PC desaturase genes cosegregate with quantitative trait loci underlying high stearic and high oleic acid mutant phenotypes in sunflower. Theor Appl Genet 104:338349. doi:10.1007/s001220100712

Pérez-Vich B, Muñoz-Ruz J, Fernández-Martínez JM (2004) Developing mid-stearic acid sunflower lines from a high stearic acid mutant. Crop Sci 44:70-75. doi:10.2135/cropsci2004.7000b

Perez-Vich B, Knapp SJ, Leon AJ, Fernandez-Martinez JM, Berry ST (2004a) Mapping minor QTL for increased stearic acid content in sunflower seed oil. Mol Breed 13:313-322. doi:10.1023/B:MOLB. 0000034081.40930.60

Pérez-Vich B, Leon AJ, Grondona M, Velasco L, Fernández-Martinez JM (2006) Molecular analysis of the high stearic acid content in sunflower mutant CAS-14. Theor Appl Genet 112:867-875. doi:10. 1007/s00122-005-0188-8

Pleite R, Martínez-Force E, Garcés R (2006) Increase of the stearic acid content in high-oleic sunflower (Helianthus annuus) seeds. J Agric Food Chem 54(25):9383-9388. doi:10.1021/jf061654f

Uryu Y et al (2008) Deforestation, forest degradation, biodiversity loss and $\mathrm{CO} 2$ emissions in Riau, Sumatra, Indonesia, WWF Indonesia Technical Report, Jakarta

Valenzuela A, Delplanque B, Tavella M (2011) El ácido esteárico: un posible sustituto para los ácidos grasos trans de origen industrial (Stearic acid: a possible substitute for trans fatty acids from industrial sources). Grasas Aceites 62(2):131-138. doi:10.3989/gya. 033910

van der Werf GR, Morton DC, DeFries RS, Olivier JGJ, Kasibhatla PS, Jackson RB, Collatz GJ, Randerson JT (2009) CO2 emissions from forest loss. Nat Geosci 2(11):737-738. doi:10.1038/ngeo671

WHO (2003) Diet, nutrition and the prevention of chronic diseases, WHO Technical Report Series 916, Report of a Joint WHO/FAO Expert Consultation, World Health Organization, Geneva

Zheljazkov VD, Vick BA, Baldwin NB, Astatkie T, Johnson B (2009) Oil content and saturated fatty acids in sunflower as a function of planting date, nitrogen rate and hybrid. Agron J 101:1003-1011. doi:10. 2134/agronj2009.0011 